\title{
The value of [68Ga]Ga-DOTA-TATE PET/CT in diagnosis and management of suspected pituitary tumors
}

Fuad Novruzov ${ }^{1,2^{*}}$ D, Aziz Aliyev ${ }^{3}$, Ming Young S. Wan², Rizwan Syed ${ }^{2}$, Elnur Mehdi ${ }^{1}$, Irada Aliyeva ${ }^{4}$, Francesco Giammarile ${ }^{5}$, Jamshed B. Bomanji ${ }^{2}$ and Irfan Kayani ${ }^{2}$

\author{
* Correspondence: drnovruzov@ \\ gmail.com \\ 'Department of Nuclear Medicine, \\ Azerbaijan National Centre of \\ Oncology, M. Xiyabani street 137, \\ AZ 1011 Baku, Azerbaijan \\ ${ }^{2}$ Institute of Nuclear Medicine, \\ University College London Hospital, \\ London, UK \\ Full list of author information is \\ available at the end of the article
}

\begin{abstract}
Background: Gallium 68-tetraazacyclododecane-tetraacetic acid-octreotate ([68Ga]Ga-DOTA-TATE) is a selective somatostatin analogue ligand, which shows increased affinity for somatostatin receptor subtype (SSTR) 2 and has been used routinely for imaging neuroendocrine tumors with PET/CT. We investigated the utility of [68Ga]Ga-DOTA-TATE positron emission tomography/computed tomography (PET/ $\mathrm{CT}$ ) in patients with suspected pituitary pathology. We reviewed imaging for twenty consecutive patients ( 8 men, 12 women, mean age of 48.2, range 14-78) with suspected pituitary pathology who were referred for [68Ga]Ga-DOTA-TATE PET/CT.

Results: Nine patients presented with recurrent Cushing's syndrome following surgical resection of pituitary adenomas due to recurrent Cushing's disease (seven patients) and ectopic ACTH secreting tumor (2 patients). All seven patients with recurrent Cushing's disease showed positive pituitary [68Ga]Ga-DOTA-TATE uptake while both cases of ectopic hormonal secretion had absented pituitary uptake. In 1 of these 2 patients, [68Ga]Ga-DOTA-TATE was able to localize the source of ectopic ACTH tumor.

Six patients presented de novo with Cushing's due to ectopic ACTH secretion; [68Ga]Ga-DOTA-TATE PET/CT was able to localize ectopic tumors in six of eight patients (3 lungs, 2 pancreases, 1 mid-gut)

There was high uptake [68Ga]Ga-DOTA-TATE in 3 cases of recurrent central hyperthyroidism (SUVmax 6.6-14.3) and 2 cases of prolactinoma (SUVmax 5.5 and 11.3).

Conclusion: Absent [68Ga]Ga-DOTA-TATE activity in the pituitary fossa is useful in excluding pituitary disease in recurrent Cushing's. Recurrent pituitary thyrotropinomas and prolactinomas showed moderate to high pituitary activity. In addition, in Cushing's syndrome, [68Ga]Ga-DOTA-TATE is useful for detection of ectopic sources of ACTH production, especially where anatomic imaging is negative.
\end{abstract}

(c) The Author(s). 2021 Open Access This article is licensed under a Creative Commons Attribution 4.0 International License, which permits use, sharing, adaptation, distribution and reproduction in any medium or format, as long as you give appropriate credit to the original author(s) and the source, provide a link to the Creative Commons licence, and indicate if changes were made. The images or other third party material in this article are included in the article's Creative Commons licence, unless indicated otherwise in a credit line to the material. If material is not included in the article's Creative Commons licence and your intended use is not permitted by statutory regulation or exceeds the permitted use, you will need to obtain permission directly from the copyright holder. To view a copy of this licence, visit http://creativecommons.org/licenses/by/4.0/. 


\section{Introduction}

Neuroendocrine tumors (NET) cover a heterogeneous group of tumors, which originate from endocrine glands (pituitary, parathyroid, adrenal medulla) or other endocrine organs like thyroid, pancreas, respiratory, and gastrointestinal tissue.

As most NETs express somatostatin receptors, they can be adequately targeted and visualized with somatostatin receptor radio-labeled analogs in vivo (Guyton and Hall 2000; Newell-Price et al. 2006; Gadelha and Vieira 2014; Bombardieri et al. 2001).

The use of Gallium 68-tetraazacyclododecane-tetraacetic acid-octreotate ([68Ga]GaDOTA-TATE labeled for the somatostatin receptor scintigraphy (SRS) is based on the increased affinity of [68Ga]Ga-DOTA-TATE labeled somatostatin receptor ligands relative to ${ }^{111}$ In-octreotide (Newell-Price et al. 2006; Gadelha and Vieira 2014; Bombardieri et al. 2001; Balon et al. 2001; Bombardieri et al. 2010). European Neuroendocrine Tumor Society guidelines (Balon et al. 2001; Haug et al. 2010) recommend the use of PET/CT for the localization of the primary tumor in metastatic NETs (Kwekkeboom et al. 2009).

The aim of our study was to evaluate the utility of [68Ga]Ga-DOTA-TATE PET/CT imaging scan in patients with suspected pituitary pathology. Patients were divided into two broad groups: those with ACTH dependent Cushing's syndrome and those with recurrent prolactinomas and thyrotropinomas.

Cushing's syndrome is a hormonal imbalance due to abnormally increased levels of cortisol hormone in blood. Cushing's syndrome is divided into 2 types: ACTHdependent and $\mathrm{ACTH}$-independent forms. In ACTH-dependent type, there is oversynthesis of ACTH from pituitary adenoma, called Cushing's disease (CD), or ectopic secretion of ACTH from peripheral tumors (Antunes et al. 2007). CD is the most common form of endogenous Cushing's syndrome, accounting for approximately $70 \%$ of cases (Pape et al. 2012; Prasad et al. 2010). Ectopic ACTH secretion is a cause of approximately $15-20 \%$ of ACTH-dependent Cushing's syndrome (Tabarin et al. 1999). In the literature, several small case series studies have reported on use of [68Ga]Ga-peptide ligands to evaluate ectopic ACTH secreting tumors (Tsagarakis et al. 2003; Veit et al. 2013; Singer et al. 2010; Haug et al. 2012). Prolactinomas are relatively common primary pituitary neoplasms whereas thyrotropinomas are rare. In both cases, however, there is very limited literature on use of somatostatin receptor imaging in vivo.

\section{Methods}

\section{Patients}

A search of our Institutional database over 5-year period between 2008 and 2013 revealed 20 consecutive patients ( 8 male, 12 females with mean age 48.2 years (range 1478 years)) who underwent [68Ga]Ga-DOTA-TATE PET/CT for evaluation of pituitary pathology.

The indication for [68Ga]Ga-DOTA-TATE PET/CT were as follows (Table 1):

a) Suspected recurrent Cushing's disease following previous surgical resection

b) $\mathrm{ACTH}$ dependent Cushing syndrome secondary to suspected ectopic ACTH production

c) Recurrent central hyperthyroidism 
Table 1 Patients' demographic and clinical characteristic

\begin{tabular}{ll}
\hline Total number of enrolled patients & $\mathbf{2 0}$ \\
\hline Gender of patients & 8 \\
Male & 12 \\
Female & \\
Clinical presentation & 9 \\
Suspicious recurrent Cushing disease & 6 \\
ACTH-dependent ectopic Cushing syndrome & 3 \\
Recurrent central hyperthyroidism & 2 \\
Recurrent galactorrhea & 2 \\
\hline
\end{tabular}

d) Recurrent prolactinoma

\section{PET/CT acquisition parameters}

Images were acquired 45-60 min after injection of 120-200 MBq of [68Ga]Ga-DOTATATE. Imaging was performed using a dedicated GE Discovery STE camera combining a PET unit and a 16-slice CT unit; whole-body examinations (brain to mid-thigh) were performed with the patient supine. The CT exposure factors for all examinations were $120 \mathrm{kVp}$ and $80 \mathrm{~mA}$ in $0.8 \mathrm{~s}$. Maintaining patient position, we performed a whole-body PET emission scan covering an area identical to that covered by CT. PET scans were acquired at a rate of $4 \mathrm{~min}$ per bed position, and PET images were reconstructed using $\mathrm{CT}$ for attenuation correction. The [68Ga]Ga-DOTA-TATE PET acquisitions were performed in 3 dimensions with a 5-slice overlap between consecutive bed positions. Ga68-DOTATATE PET images were reconstructed using an ordered-subsets expectation maximization algorithm with 3 iterations and 25 subsets. The CT data for [68Ga]GaDOTA-TATE were reconstructed to axial slices $3.75 \mathrm{~mm}$ thick with a soft-tissue reconstruction algorithm and $2.5 \mathrm{~mm}$ thick with a lung reconstruction algorithm.

\section{Image analysis}

The documented clinical reports were used to determine results of [68Ga]Ga-DOTATATE PET/CT scans. The presence or absence of uptake at the suspected lesion level allowed to classify the 20 patients in "positive" and "negative" respectively. In addition, scans were retrospectively reviewed to document standardized uptake value (SUVmax) in all lesions.

Histological confirmation of tumor type was available for all patients except for one case where ectopic ACTH source for Cushing syndrome was unknown.

All patients had informed consent, and institutional board ethics approval was received for this retrospective study.

\section{Results}

Tumor overview, histology assessment, and [68Ga]Ga-DOTA-TATE uptake are summarized in Table 2.

Fifteen patients had Cushing's syndrome. Of these 15, nine presented with recurrent Cushing's following surgical treatment for Cushing's disease. Six out of 15 patients presented de novo with ectopic ACTH-dependent Cushing's syndrome. In 7/9 patients 
Table 2 Summary of tumor characteristic and finding

\begin{tabular}{|c|c|c|c|c|c|}
\hline $\begin{array}{l}\text { Patients } \\
\text { No }\end{array}$ & $\begin{array}{l}\text { Age, } \\
\text { sex }\end{array}$ & Referral presentation & $\begin{array}{l}\text { Previous } \\
\text { treatment } \\
(P S / R T)\end{array}$ & $\begin{array}{l}\text { Tumor } \\
\text { site }{ }^{88} \mathrm{Ga}- \\
\mathrm{PET} / \mathrm{CT} \\
\text { uptake }\end{array}$ & Final diagnosis/histology \\
\hline 1 & $\begin{array}{l}68, \\
M\end{array}$ & $\begin{array}{l}\text { Suspected recurrent } \\
\text { Cushing disease }\end{array}$ & PS & $\begin{array}{l}\text { Pituitary } \\
\text { fossa } \\
\text { (SUVmax } \\
\text { 2.3) }\end{array}$ & $\begin{array}{l}\text { CD/pituitary adenoma with expression of } \\
\text { ACTH }\end{array}$ \\
\hline 2 & $\begin{array}{l}37, \\
M\end{array}$ & $\begin{array}{l}\text { Suspected recurrent } \\
\text { Cushing disease }\end{array}$ & PS & $\begin{array}{l}\text { Pituitary } \\
\text { fossa } \\
\text { (SUVmax } 4.2\end{array}$ & $\begin{array}{l}\text { CD/pituitary adenoma with expression of } \\
\text { ACTH }\end{array}$ \\
\hline 3 & $57, \mathrm{~F}$ & $\begin{array}{l}\text { Suspected recurrent } \\
\text { Cushing disease }\end{array}$ & PS & $\begin{array}{l}\text { Pituitary } \\
\text { fossa } \\
\text { (SUVmax } \\
4.2 \text { ) }\end{array}$ & $\begin{array}{l}\text { CD/atypically pituitary adenoma with } \\
\text { expression of ACTH }\end{array}$ \\
\hline 4 & $49, F$ & $\begin{array}{l}\text { Suspected recurrent } \\
\text { Cushing disease }\end{array}$ & PS & $\begin{array}{l}\text { Pituitary } \\
\text { fossa } \\
\text { (SUVmax } \\
\text { 3.1) }\end{array}$ & $\begin{array}{l}\text { Pituitary adenocarcinoma with } \\
\text { expression of ACTH }\end{array}$ \\
\hline 5 & $\begin{array}{l}26, \\
M\end{array}$ & $\begin{array}{l}\text { Suspected recurrent } \\
\text { Cushing disease }\end{array}$ & PS & $\begin{array}{l}\text { Pituitary } \\
\text { fossa } \\
\text { (SUVmax } \\
\text { 6.1) }\end{array}$ & $\begin{array}{l}\text { CD/pituitary adenoma with expression of } \\
\text { ACTH }\end{array}$ \\
\hline 6 & $78, F$ & $\begin{array}{l}\text { Suspected recurrent } \\
\text { Cushing disease }\end{array}$ & $P S+R T$ & $\begin{array}{l}\text { Pancreas } \\
\text { (SUVmax } \\
\text { 8.4) }\end{array}$ & Pancreatic NET's with expression of ACTH \\
\hline 7 & $30, F$ & $\begin{array}{l}\text { Suspected recurrent } \\
\text { Cushing disease, } \\
\text { central } \\
\text { hyperthyroidism }\end{array}$ & PS & $\begin{array}{l}\text { Pituitary } \\
\text { fossa } \\
\text { (SUVmax } \\
\text { 5.2) }\end{array}$ & $\begin{array}{l}\text { CD+ TSH-oma/plurihormonal pituitary } \\
\text { adenoma with expression of TSH, FSH, } \\
\text { and ACTH }\end{array}$ \\
\hline 8 & $68, F$ & $\begin{array}{l}\text { Suspected recurrent } \\
\text { Cushing disease }\end{array}$ & PS & $\begin{array}{l}\text { Pituitary } \\
\text { fossa } \\
\text { (SUVmax } \\
\text { 3.9) }\end{array}$ & $\begin{array}{l}\text { Cyclical CD/adenoma with expression of } \\
\text { ACTH }\end{array}$ \\
\hline 9 & $67, F$ & $\begin{array}{l}\text { Suspected recurrent } \\
\text { Cushing disease }\end{array}$ & PS & Negative & $\begin{array}{l}\text { Ectopic ACTH secreting tumor, unknown } \\
\text { source }\end{array}$ \\
\hline 10 & $73, F$ & $\begin{array}{l}\text { Ectopic Cushing } \\
\text { syndrome }\end{array}$ & NO & Negative & Pancreatic NET's with expression of ACTH \\
\hline 11 & $\begin{array}{l}14 \\
M\end{array}$ & $\begin{array}{l}\text { Ectopic Cushing } \\
\text { syndrome }\end{array}$ & NO & $\begin{array}{l}\text { Lung } \\
\text { nodule } \\
\text { (SUVmax1.4) }\end{array}$ & $\begin{array}{l}\text { Atypical lung carcinoid with expression } \\
\text { ACTH }\end{array}$ \\
\hline 12 & $\begin{array}{l}58, \\
M\end{array}$ & $\begin{array}{l}\text { Ectopic Cushing } \\
\text { syndrome }\end{array}$ & NO & $\begin{array}{l}\text { Lung } \\
\text { nodule } \\
\text { (SUVmax } \\
1.9 \text { ) }\end{array}$ & $\begin{array}{l}\text { Typical lung carcinoid with expression of } \\
\text { ACTH }\end{array}$ \\
\hline 13 & $22, F$ & $\begin{array}{l}\text { Ectopic Cushing } \\
\text { syndrome }\end{array}$ & NO & $\begin{array}{l}\text { Lung } \\
\text { nodule } \\
\text { (SUVmax } \\
\text { 2.0) }\end{array}$ & $\begin{array}{l}\text { Typical lung carcinoid with expression of } \\
\text { ACTH }\end{array}$ \\
\hline 14 & $42, F$ & $\begin{array}{l}\text { Ectopic Cushing } \\
\text { syndrome }\end{array}$ & NO & $\begin{array}{l}\text { Small bowel } \\
\text { (SUVmax } \\
\text { 25.3) }\end{array}$ & $\begin{array}{l}\text { Metastatic mid-gut NET's with expression } \\
\text { of ACTH }\end{array}$ \\
\hline 15 & $49, \mathrm{~F}$ & $\begin{array}{l}\text { Ectopic Cushing } \\
\text { syndrome }\end{array}$ & NO & $\begin{array}{l}\text { Head of } \\
\text { pancreas } \\
\text { (SUVmax } \\
35.5\end{array}$ & Pancreatic NET's with expression of ACTH \\
\hline 16 & $\begin{array}{l}27, \\
M\end{array}$ & $\begin{array}{l}\text { Recurrent central } \\
\text { hyperthyroidism }\end{array}$ & PS & $\begin{array}{l}\text { Pituitary } \\
\text { fossa } \\
\text { (SUVmax } \\
\text { 6.6) }\end{array}$ & $\begin{array}{l}\text { TSH-Oma/pituitary adenoma with } \\
\text { expressing of TSH }\end{array}$ \\
\hline
\end{tabular}


Table 2 Summary of tumor characteristic and finding (Continued)

\begin{tabular}{|c|c|c|c|c|c|}
\hline $\begin{array}{l}\text { Patients } \\
\text { No }\end{array}$ & $\begin{array}{l}\text { Age, } \\
\text { sex }\end{array}$ & Referral presentation & $\begin{array}{l}\text { Previous } \\
\text { treatment } \\
(P S / R T)\end{array}$ & $\begin{array}{l}\text { Tumor } \\
\text { site }{ }^{68} \mathrm{Ga}- \\
\mathrm{PET} / \mathrm{CT} \\
\text { uptake }\end{array}$ & Final diagnosis/histology \\
\hline 17 & $\begin{array}{l}48, \\
M\end{array}$ & $\begin{array}{l}\text { Recurrent central } \\
\text { hyperthyroidism }\end{array}$ & PS & $\begin{array}{l}\text { Pituitary } \\
\text { fossa } \\
\text { (SUVmax } \\
6.7 \text { ) }\end{array}$ & $\begin{array}{l}\text { TSH-Oma/pituitary adenoma with } \\
\text { expressing of TSH }\end{array}$ \\
\hline 18 & $50, F$ & $\begin{array}{l}\text { Recurrent central } \\
\text { hyperthyroidism }\end{array}$ & PS & $\begin{array}{l}\text { Pituitary } \\
\text { fossa } \\
\text { (SUVmax } \\
14.3 \text { ) }\end{array}$ & $\begin{array}{l}\text { TSH-Oma/pituitary adenoma with } \\
\text { expressing of TSH }\end{array}$ \\
\hline 19 & $\begin{array}{l}23 \\
M\end{array}$ & Pituitary mass & EBRT & $\begin{array}{l}\text { Pituitary } \\
\text { fossa } \\
\text { (SUVmax } \\
5.5 \text { ) }\end{array}$ & $\begin{array}{l}\text { Prolactinoma/pituitary adenoma with } \\
\text { expression of prolactin }\end{array}$ \\
\hline 20 & $34, F$ & Recurrent galactorrhea & NO & $\begin{array}{l}\text { Pituitary } \\
\text { fossa } \\
\text { (SUVmax } \\
11.3 \text { ) }\end{array}$ & $\begin{array}{l}\text { Prolactinoma/pituitary adenoma with } \\
\text { expression of prolactin }\end{array}$ \\
\hline
\end{tabular}

PS pituitary surgery, EBRT external beam radiation therapy, CD Cushing's disease, ACTH adrenocorticotropic hormone, TSH thyroid stimulating hormone, NET neuroendocrine tumor

with recurrent Cushing's syndrome, there was recurrent pituitary disease. In 2/9 patients, recurrent Cushing's syndrome was due to ectopic ACTH producing tumor.

The source of ectopic ACTH was due to bronchial carcinoid (3 patients), pancreatic NETs (2 patients), and mid gut NET (1 patient). Of 3 bronchial carcinoid tumors, 2 were typical carcinoid $(0.8$ and $1.7 \mathrm{~cm})$ and 1 was atypical carcinoid $(1.5 \mathrm{~cm})$. In one patient, ectopic source of ACTH production was unknown.

In all seven patients with recurrent Cushing's secondary to recurrent Cushing's disease, there was positive uptake of [68Ga]Ga-DOTA-TATE within pituitary (SUVmax 2.3-6.1, mean 4.1). In both cases of recurrent Cushing's due to ectopic ACTH production, there was absent uptake of [68Ga]Ga-DOTA-TATE in the pituitary. Pituitary uptake in those with recurrent pituitary adenomas was less intense than pituitary uptake seen in patients presenting de novo with ectopic Cushing's (SUVmax 4.8-8.9, mean 6.2).

[68Ga]Ga-DOTA-TATE was able to depict source of ectopic ACTH production in six of eight patients ( $1 / 2$ patients with recurrent Cushing's syndrome, and 5/6 patients presenting de novo). [68Ga]Ga-DOTA-TATE showed positive but low uptake (Fig. 1) in all three bronchial carcinoids (SUVmax 1.4-2.0). There was high [68Ga]Ga-DOTATATE uptake in 1/2 Pancreatic NETs (SUVmax 35.5) and one Mid-Gut NET (SUVmax 25.3) (Fig. 2).

In one with negative [68Ga]Ga-DOTA-TATE uptake, ectopic source of tumor was not shown on any imaging modality, ectopic tumor ACTH production was diagnosed biochemically and on basis of complete resection of pituitary tissue (shown on MRI) as well absent pituitary [68Ga]Ga-DOTA-TATE activity (Fig. 3). In another with pancreatic NET, there was negative [68Ga]Ga-DOTA-TATE uptake as well as negative CT and MRI with tumor depicted only on EUS.

In one case with unknown primary site on conventional CT/MRI imaging Ga[68Ga]Ga-DOTA-TATE showed site of primary tumor (in terminal ileum). 

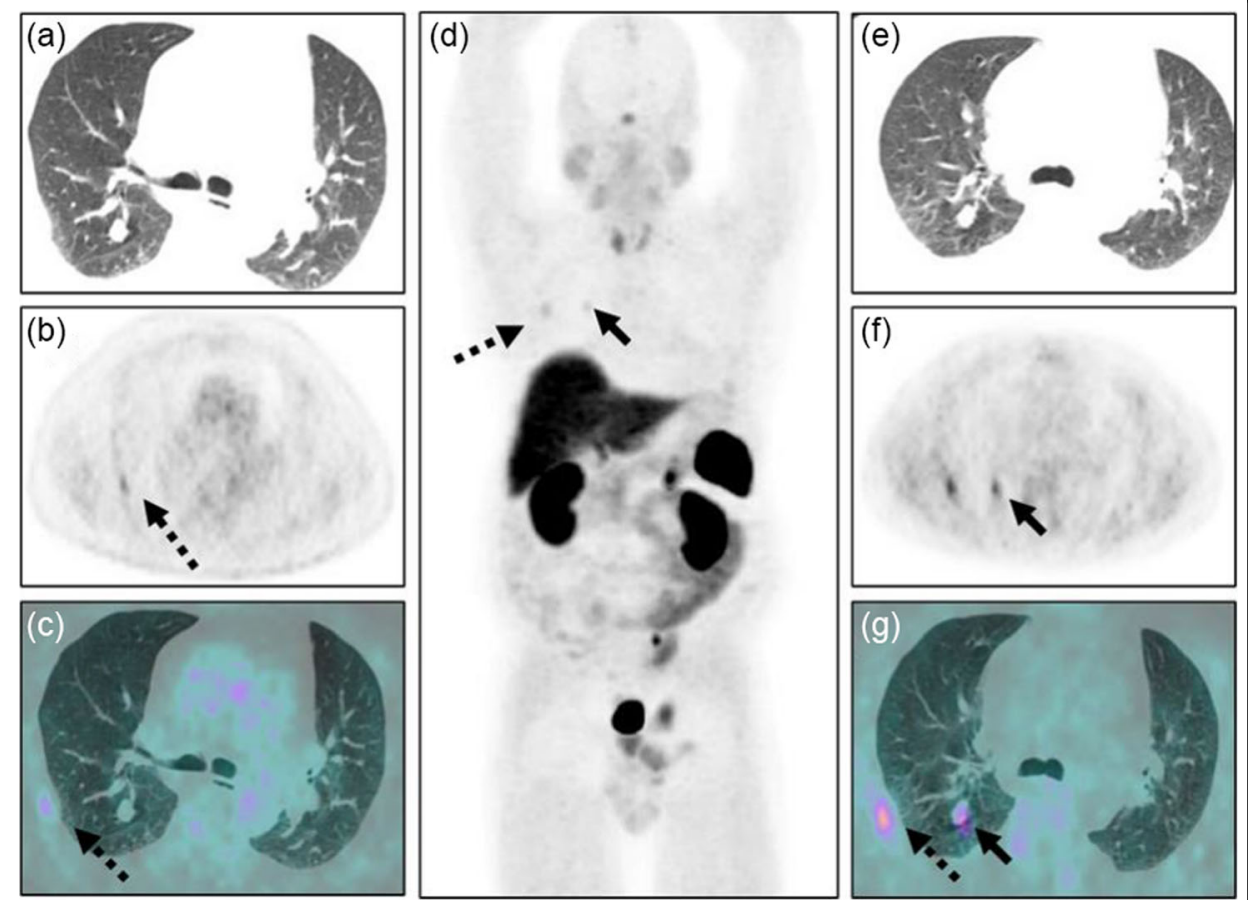

Fig. 1 A 58-year-old man was presented with ectopic ACTH secreting Cushing syndrome. FDG PET/CT images (a-c) showed a non-avid lung nodule. MIP, trans-axial CT, PET, and fused PET/CT images (d-g) show mild focal [68Ga]Ga-DOTA-TATE uptake (SUVmax 1.9) in right lower lobe nodule (black filled arrows). Postsurgery histological diagnosis was typical bronchial carcinoid secreting ACTH. After surgery Cushing's symptoms is cured. Uptake is also seen with FDG $(\mathbf{b}, \mathbf{c})$ and $[68 \mathrm{Ga}] \mathrm{Ga}$-DOTA-TATE $(\mathbf{d}, \mathbf{f}, \mathbf{g})$ PET/CT due to a rib fracture (black dashed arrows)

Three patients presented with recurrent central hyperthyroidism due to thyroid stimulating hormone (TSH) secreting adenoma following previous surgical resection, with increased TSH and free-thyroid hormone levels, and residual pituitary macro adenomas on MRI (size $13 \mathrm{~mm}$, range 11-15 mm). All patients with recurrent thyrotropinomas showed high tracer uptake (Fig. 4) within pituitary (mean SUVmax 9.2, range 6.7-14.3). Two patients with pituitary adenoma secondary to prolactinoma showed moderate to high [68Ga]Ga-DOTA-TATE uptake in pituitary gland (SUVmax 5.5 and 11.3).

\section{Discussion}

Our study suggests that, in selected indications, [68Ga]Ga-DOTA-TATE has a useful role in evaluating patients with suspected pituitary pathology.

[68Ga]Ga-DOTA-TATE activity within the pituitary fossa is a marker for functioning pituitary tissue, a property which can help assess patients with recurrent Cushing's syndrome following resection of corticotrophin secreting pituitary tumors. Positive pituitary uptake indicates the presence of functioning pituitary tissue; in all seven patients with recurrent Cushing's disease, there was positive uptake within pituitary although this was less than normal pituitary activity seen in those with Cushing's due to ectopic ACTH secretion. Our findings are in keeping with Zhao et al. who showed that [68Ga]Ga-DOTA-TATE had higher uptake in normal remaining pituitary tissue than in recurrent or residual pituitary adenomas (Invitti et al. 1999). In contrast, both 


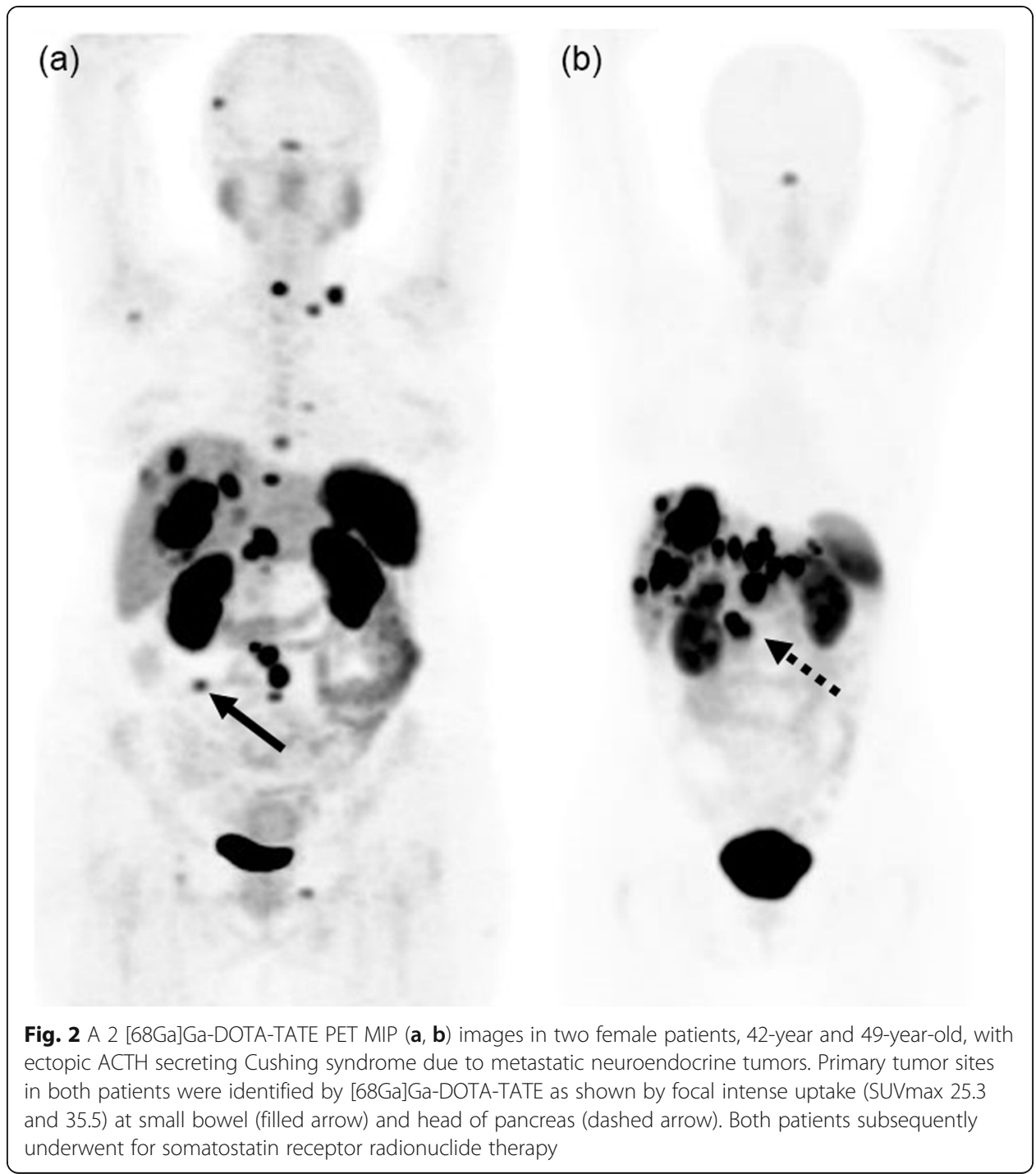

patients with recurrent Cushing's syndrome due to ectopic ACTH secretion had no uptake within pituitary, in keeping with treated pituitary disease.

The diagnosis of Cushing's disease can be challenging. The best imaging modality, MRI, may be normal in up to $40 \%$ of patients (Swearingen et al. 2004). Inferior petrosal sinus sampling (IPSS) is the gold standard for differentiating between pituitary and non-pituitary sources of corticotrophin, with diagnostic accuracy of $87 \%$ (Swearingen et al. 2004) but is a highly skilled and invasive technique, requiring placement of catheters in both inferior petrosal sinuses (Zhao et al. 2014). [68Ga]Ga-DOTA-TATE is also useful in localization of ectopic ACTH producing tumors. Ectopic ACTH secretion is an infrequent cause of ACTH-dependent Cushing's syndrome. It often presents a major diagnostic difficulty because it is hard to differentiate Cushing's disease from ectopic tumors and is often difficult to localize. [68Ga]Ga-DOTA-TATE could detect ectopic ACTH source in 5/6 patients presenting de novo with ACTH-dependent Cushing's and $1 / 2$ patients with treated pituitary Cushing's. Three with ectopic Cushing's had lung carcinoid. Although pulmonary carcinoids showed positive uptake of [68Ga]Ga-DOTATATE, the level of accumulation was unusually low (SUVmax 1.4-2.0). 

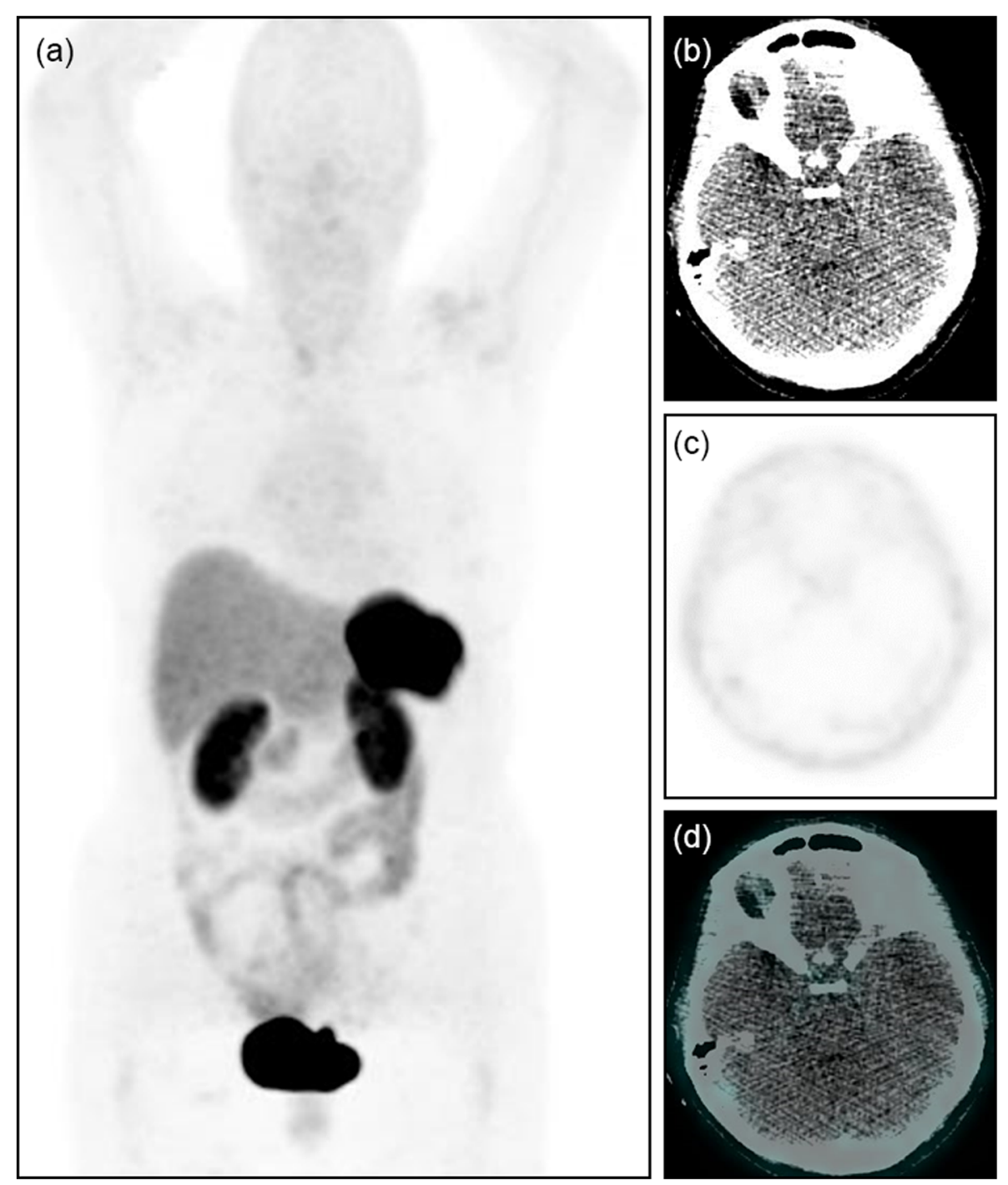

Fig. 3 A 67-year-old woman history of surgical resection for ACTH pituitary macro-adenoma was referred with suspected recurrent Cushing disease. PET MIP (a), trans-axial CT, PET, and fused PET/CT images (b-d) show no [68Ga]Ga-DOTA-TATE uptake in pituitary fossa in keeping with prior curative resection. MRI showed no glandular tissue in pituitary fossa. The source of recurrent ACTH in this case was unknown

There are varying results regarding use of conventional single photon somatostatin receptor scintigraphy (SRS) for evaluating patients with ectopic Cushing syndrome with majority of published studies (Tabarin et al. 1999; Tsagarakis et al. 2003; Özkan et al. 2013; Ejaz et al. 2011; Torpy et al. 1999; Zemskova et al. 2010; Ilias et al. 2005; Isidori et al. 2006; Doi et al. 2010; Kakade et al. 2013; Gilardi et al. 2014) reporting sensitivity of between 40 and $60 \%$. In the two largest published studies by Zemskova et al. and Ilias et al. SRS could detect ectopic tumor in (17/30) 57\% and (21/43) 49\% (Zemskova et al. 2010; Ilias et al. 2005). Studies comparing SRS with diagnostic CT/MRI have found limited role for SRS as no additional lesions were detected with SRS relative to CT/MRI (Haug et al. 2010; Özkan et al. 2013; Ejaz et al. 2011).

Studies evaluating [68Ga]Ga-DOTA-TATE-labeled somatostatin ligands are limited to a small number of case reports and very small case series (Özkan et al. 2013; Kakade et al. 

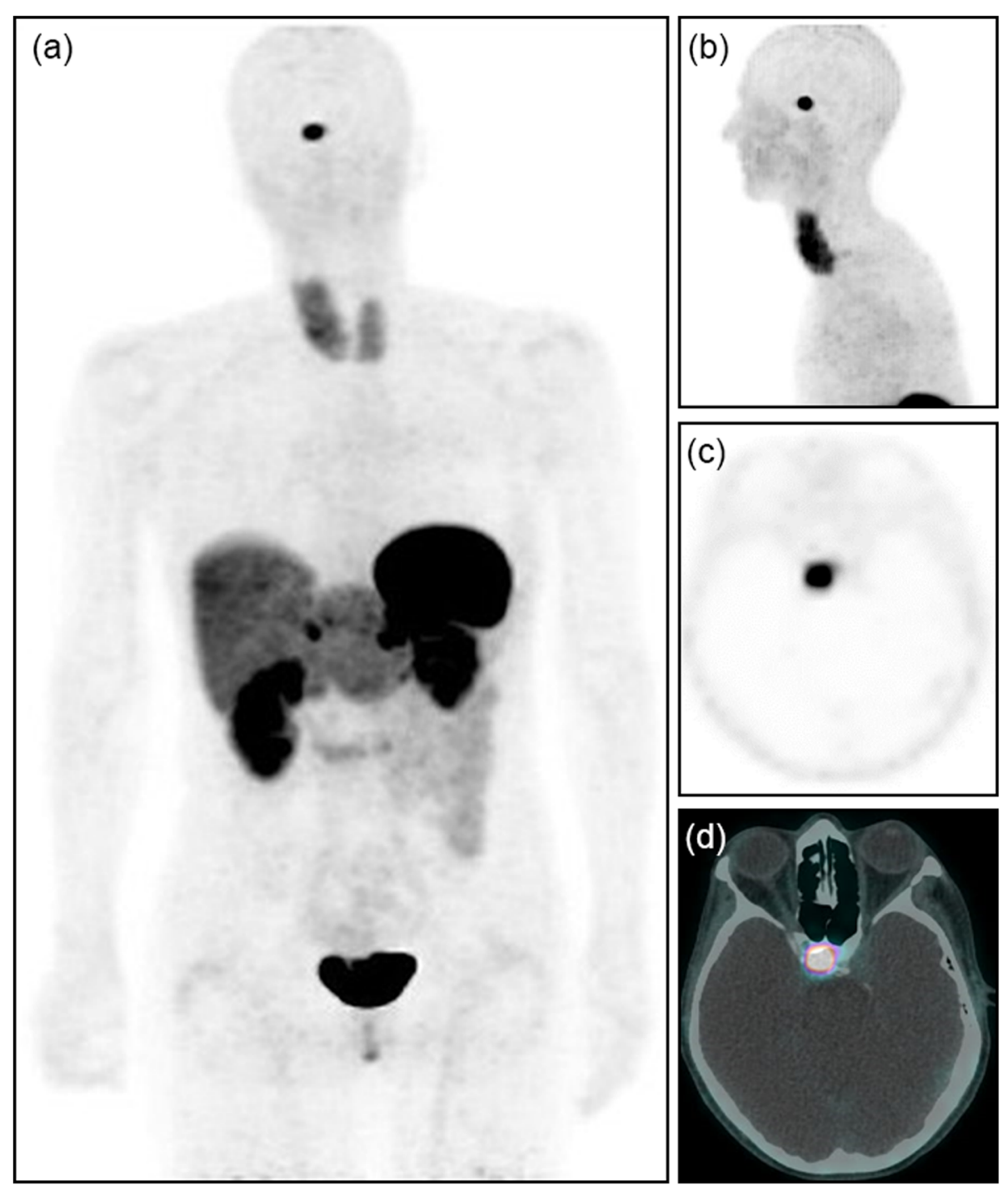

Fig. 4 A 50-year-old woman was referred with recurrent central hyperthyroidism, 2 year post pituitary surgery for a TSH secreting micro-adenoma. [68Ga]Ga-DOTA-TATE PET MIP (a, b), trans-axial PET, and fused PET/CT images (c, d) clearly depict increased focal uptake (SUVmax 14.3) in pituitary fossa. The patient underwent repeat surgical resection of recurrent pituitary adenoma (Thyrotropinoma)

2013; Gilardi et al. 2014; Venkitaraman et al. 2014; Treglia et al. 2013; Därr et al. 2012; Thomas et al. 2013; Willhauck et al. 2012; Schalin-Jäntti et al. 2012; Gani et al. 2011). The sensitivity of [68Ga]Ga-DOTA-TATE in detecting source of ectopic ACTH secretion from previously published cases is approximately $72 \%$ (18/25 patients) (Table 3). Ozkan et al. (Özkan et al. 2013) found positive Ga-68-DOTATATE uptake in only 2/5 patients with ectopic ACTH syndrome; one patient showed false positive uptake. In contrast, Gilardi et al. reported that [68Ga]Ga-DOTA-TATE revealed the source of ectopic lesions in 5/5 patients with ectopic ACTH syndrome (Gilardi et al. 2014). In 3/5 patients, SRS with [111In]In-pentetreotide had failed to localize the source of ACTH secretion. Kakade et al. reported that [68Ga]Ga-DOTA-TATE was positive in 4/6 ectopic ACTH secreting tumor including two which had negative CT (Kakade et al. 2013). In our series, 6 of 8 ectopic ACTH secreting tumors were detected with [68Ga]Ga-DOTA-TATE; in one case, 
Table 3 Study of ectopic ACTH PET-CT scan with ${ }^{68} \mathrm{Ga-DOTA}$ peptides

\begin{tabular}{|c|c|c|c|c|c|}
\hline Studies & Patients & $\begin{array}{l}\text { Positive uptake } \\
\text { within ectopic } \\
\text { tumor }\end{array}$ & $\begin{array}{l}\text { Negative uptake } \\
\text { within ectopic } \\
\text { tumor }\end{array}$ & Tracer & Tumor types \\
\hline $\begin{array}{l}\text { Veit et al. } \\
\text { (2013) }\end{array}$ & 1 & 1 & 0 & $\begin{array}{l}{ }^{68} \mathrm{Ga}- \\
\text { DOTANOC }\end{array}$ & Paranasal adenoma \\
\hline $\begin{array}{l}\text { Singer et al. } \\
(2010)\end{array}$ & 1 & 1 & 0 & $\begin{array}{l}{ }^{68} \mathrm{Ga}- \\
\text { DOTATOC }\end{array}$ & lleum carcinoma \\
\hline $\begin{array}{l}\text { Ozkan et al. } \\
\text { (2013) }\end{array}$ & 5 & 2 & $3^{*}$ & $\begin{array}{l}{ }^{68} \mathrm{Ga}- \\
\text { DOTATATE }\end{array}$ & $\begin{array}{l}\text { Bronchial carcinoid-1, } \\
\text { metastatic atypical } \\
\text { carcinoid-1 }\end{array}$ \\
\hline $\begin{array}{l}\text { Kakade et al. } \\
\text { (2013) }\end{array}$ & 6 & 4 & 2 & $\begin{array}{l}{ }^{68} \mathrm{Ga}- \\
\text { DOTATATE }\end{array}$ & $\begin{array}{l}\text { Bronchial carcinoid-1, } \\
\text { PNET-1, MTC-2 }\end{array}$ \\
\hline $\begin{array}{l}\text { Gilardi et al. } \\
\text { (2014) }\end{array}$ & 5 & 5 & 0 & $\begin{array}{l}{ }^{68} \mathrm{Ga}- \\
\text { DOTATOC }\end{array}$ & Bronchial carcinoid \\
\hline $\begin{array}{l}\text { Venkitaraman } \\
\text { et al. (2014) }\end{array}$ & 3 & 3 & 0 & $\begin{array}{l}{ }^{68} \mathrm{Ga}- \\
\text { DOTATOC }\end{array}$ & Bronchial carcinoid \\
\hline $\begin{array}{l}\text { Treglia et al. } \\
\text { (2013) }\end{array}$ & 1 & 1 & 0 & $\begin{array}{l}{ }^{68} \mathrm{Ga}- \\
\text { DOTANOC }\end{array}$ & PNET \\
\hline $\begin{array}{l}\text { Darr et al. } \\
\text { (2012) }\end{array}$ & 1 & 1 & 0 & $\begin{array}{l}{ }^{68} \mathrm{Ga}- \\
\text { DOTATATE }\end{array}$ & Bronchial carcinoid \\
\hline $\begin{array}{l}\text { Thomas et al. } \\
\text { (2013) }\end{array}$ & 1 & 1 & 0 & $\begin{array}{l}{ }^{68} \mathrm{Ga}- \\
\text { DOTATATE }\end{array}$ & Nasal paraganglioma \\
\hline $\begin{array}{l}\text { Willhauck } \\
\text { et al. (2012) }\end{array}$ & 1 & 1 & 0 & $\begin{array}{l}{ }^{68} \mathrm{Ga}- \\
\text { DOTATATE }\end{array}$ & Sphenoid adenoma \\
\hline $\begin{array}{l}\text { Schalin-Jäntti } \\
\text { et al. (2012) }\end{array}$ & 1 & 0 & 1 & $\begin{array}{l}{ }^{68} \mathrm{Ga}- \\
\text { DOTATOC }\end{array}$ & Bronchial carcinoid \\
\hline $\begin{array}{l}\text { Gani et al. } \\
\text { (2011) }\end{array}$ & 1 & 0 & 1 & $\begin{array}{l}{ }^{68} \mathrm{Ga}- \\
\text { DOTATOC }\end{array}$ & Bronchial carcinoid \\
\hline Our study & 8 & 6 & 2 & $\begin{array}{l}{ }^{68} \mathrm{Ga}- \\
\text { DOTATATE }\end{array}$ & $\begin{array}{l}\text { Bronchial carcinoid-3, } \\
\text { ileum carcinoma-1, PNET-2 }\end{array}$ \\
\hline
\end{tabular}

MTC medullar thyroid carcinoma, PNET pancreatic neuroendocrine tumor

*One false positive

ectopic primary tumor was not seen on CT but was depicted with [68Ga]Ga-DOTATATE.

Interestingly, pituitary uptake seen in patients with recurrent pituitary adenomas was less intense than pituitary uptake in patients with de novo ectopic Cushing's syndrome (mean SUVmax 4.1 vs 6.2 respectively). The results are in line with the literature data, although absolute values of SUV are generally lower in our case (Kakade et al. 2013; Gilardi et al. 2014; Venkitaraman et al. 2014; Treglia et al. 2013; Därr et al. 2012; Thomas et al. 2013; Willhauck et al. 2012; Schalin-Jäntti et al. 2012; Gani et al. 2011).

Thyrotropinomas are a rare cause of hyperthyroidism in clinical practice often diagnosed as macro adenomas due to delayed diagnosis. Suppression of TSH secretion is mediated via both SSTR 2 and SSTR 5 subtypes (Shimon et al. 1997). Long acting somatostatin analog drugs reduce TSH secretion and normalize FT4 and FT3 levels in 90\% of patients suffering with pituitary TSH secreting tumors (Ben-Shlomo and Melmed 2010). In $25 \%$ of thyrotropinoma cases, there is autonomous secretion of a second pituitary hormone (Elhadd et al. 2009). One of our 9 patients with recurrent Cushing's syndrome also had the symptoms of central hyperthyroidism with final diagnosis of plurihormonal pituitary adenoma with expression of ACTH, FSH, and TSH (case 7, Table 2). In a study published by Foppiani et al. all 3 patients with TSH-oma were positive in octreoscan (Foppiani et al. 2007). Despite previous pituitary surgery, there was 
moderate increased [68Ga]Ga-DOTA-TATE uptake in patient with recurrent Cushing's and thyrotropinoma and intense uptake in 3 cases of recurrent thyrotropinomas (Fig. 4). Moderate to high pituitary uptake was also seen in both patients with recurrent prolactinomas.

\section{Conclusion}

[68Ga]Ga-DOTA-TATE, with integrated PET/CT, is a useful diagnostic modality for the evaluation of patients with suspected pituitary pathology. Recurrent Cushing's disease is associated with positive pituitary uptake of [68Ga]Ga-DOTA-TATE. Although in these cases it would not be possible to distinguish pathological from physiological uptake, positive [68Ga]Ga-DOTA-TATE is useful as it indicates the presence of functioning pituitary tissue. Absence of pituitary uptake in patients with recurrent Cushing's suggests source of ACTH is ectopic. Moderate to high pituitary tracer uptake of [68Ga]Ga-DOTA-TATE was seen in patients with recurrent thyrotropinomas and prolactinomas indicating [68Ga]Ga-DOTA-TATE may be useful for detection of disease post-surgery.

[68Ga]Ga-DOTA-TATE may be helpful in detecting source of ectopic lesion in Cushing's syndrome particularly in those where CT imaging is negative. Finally, locally aggressive or metastatic pituitary tumors may show [68Ga]Ga-DOTA-TATE uptake and therefore indicate potential for treatment with radio-labeled somatostatin receptor analogues such as[177Lu]Lu DOTA-TATE.

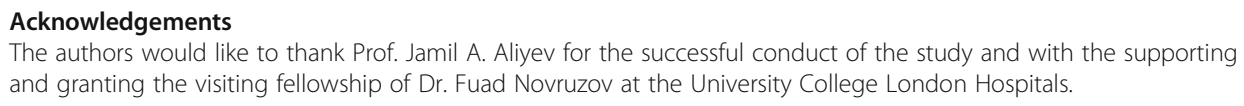

\section{Authors' contributions}

Fuad Novruzov — contributed to the design and implementation of the research, to the analysis of the results, and to the writing of the manuscript. Aziz Aliyev-were involved in planning and supervised the work. Ming Young $S$ Wan-contributed to the design and implementation of the research. Rizwan Syed-contributed to the design and implementation of the research. Elnur Mehdi-were involved for data analyses. Irada Aliyeva —were involved in planning and supervised the work. Francesco Giammarile-contributed to the supervision of the research and analysis of the results. Jamshed Bomanji-contributed to the design of the research and supervised the work. Irfan Kayani-developed the theory, wrote the manuscript, and performed the computations. All authors discussed the results and commented on the manuscript. The authors read and approved the final manuscript.

\section{Funding}

A. Supported by funding from the Department of Health and Cancer Research United Kingdom for the National Institute for Health Research Biomedical Research Centres and Experimental Cancer Medicine Centres at University College London Hospitals/University College London.

B. Science Development Foundation under the President of the Republic of Azerbaijan, Grant \# EIF-2014-9(24)-KETPL$14 / 13 / 3$

Availability of data and materials

All data and materials are available by the authors.

\section{Declarations}

Ethics approval and consent to participate

Our study is a retrospective. For this type of study, formal consent is not required.

Consent for publication

This article does not contain any studies with individual participants performed by any of the authors.

Competing interests

The authors declare that they have no conflict of interest.

\section{Author details}

${ }^{1}$ Department of Nuclear Medicine, Azerbaijan National Centre of Oncology, M. Xiyabani street 137, AZ 1011 Baku, Azerbaijan. ${ }^{2}$ Institute of Nuclear Medicine, University College London Hospital, London, UK. ${ }^{3}$ Department of Head and 
Neck Surgery, Azerbaijan National Centre of Oncology, Baku, Azerbaijan. ${ }^{4}$ Department of Internal Medicine, Azerbaijan Medical University, Baku, Azerbaijan. ${ }^{5}$ International Atomic Energy Agency, Vienna, Austria.

Received: 17 February 2021 Accepted: 20 April 2021

Published online: 24 May 2021

\section{References}

Antunes P, Ginj M, Zhang H, Waser B, Baum RP, Reubi JC, Maecke H (2007) Are radiogallium-labelled DOTA-conjugated somatostatin analogues superior to those labelled with other radiometals? Eur J Nucl Med Mol Imaging 34(7):982-993. https://doi.org/10.1007/s00259-006-0317-x

Balon HR, Goldsmith SJ, Siegel BA, Silberstein EB, Krenning EP, Lang O, Donohoe KJ, Society of Nuclear Medicine (2001) Society of Nuclear Medicine. Procedure guideline for somatostatin receptor scintigraphy with (111)In-pentetreotide. J Nucl Med 42(7):1134-1138

Ben-Shlomo A, Melmed S (2010) Pituitary somatostatin receptor signaling. Trends Endocrinol Metab 21(3):123-133. https:// doi.org/10.1016/j.tem.2009.12.003

Bombardieri E, Ambrosini V, Aktolun C, Baum RP, Bishof-Delaloye A, Del Vecchio S et al (2010) Oncology Committee of the EANM. 111 In-pentetreotide scintigraphy: procedure guidelines for tumour imaging. Eur J Nucl Med Mol Imaging 37(7): 1441-1448. https://doi.org/10.1007/s00259-010-1473-6

Bombardieri E, Maccauro M, De Deckere E, Savelli G, Chiti A (2001) Nuclear medicine imaging of neuroendocrine tumours. Ann Oncol 12(Suppl 2):S51-S61. https://doi.org/10.1093/annonc/12.suppl_2.S51

Därr R, Zöphel K, Eisenhofer G, Abolmaali N, Gastmeier J, Wieczorek K, Jelinek V, Kamvissi V, Bornstein SR, Hofbauer LC (2012) Combined use of 68Ga-DOTATATE and 18F-FDG PET/CT to localize a bronchial carcinoid associated with ectopic ACTH syndrome. J Clin Endocrinol Metab 97(7):2207-2208. https://doi.org/10.1210/jc.2012-1402

Doi M, Sugiyama T, Izumiyama H, Yoshimoto T, Hirata Y (2010) Clinical features and management of ectopic ACTH syndrome at a single institute in Japan. Endocr J 57(12):1061-1069. https://doi.org/10.1507/endocrj.K10E-265

Ejaz S, Vassilopoulou-Sellin R, Busaidy NL, Hu MI, Waguespack SG, Jimenez C, Ying AK, Cabanillas M, Abbara M, Habra MA (2011) Cushing syndrome secondary to ectopic adrenocorticotropic hormone secretion: the University of Texas MD Anderson Cancer Center Experience. Cancer. 117(19):4381-4389. https://doi.org/10.1002/cncr.26029

Elhadd TA, Ghosh S, Teoh WL, Trevethick KA, Hanzely Z, Dunn LT, Malik IA, Collier A (2009) A patient with thyrotropinoma cosecreting growth hormone and follicle-stimulating hormone with low alpha-glycoprotein: a new subentity? Thyroid. 19(8):899-903. https://doi.org/10.1089/thy.2008.0384

Foppiani L, Del Monte P, Ruelle A, Bandelloni R, Quilici P, Bernasconi D (2007) TSH-secreting adenomas: rare pituitary tumors with multifaceted clinical and biological features. J Endocrinol Investig 30(7):603-609. https://doi.org/10.1007/BF03346356

Gadelha MR, Vieira NL (2014) Efficacy of medical treatment in Cushing's disease: a systematic review. Clin Endocrinol 80(1):112. https://doi.org/10.1111/cen.12345

Gani LU, Gianatti EJ, Cheung AS, Jerums G, Macisaac RJ (2011) Failure of functional imaging with gallium-68-DOTA-D-Phe1Tyr3-octreotide positron emission tomography to localize the site of ectopic adrenocorticotropic hormone secretion: a case report. J Med Case Rep 5(1):405. https://doi.org/10.1186/1752-1947-5-405

Gilardi L, Colandrea M, Fracassi SL, Sansovini M, Paganelli G (2014) (68) Ga-DOTA(0) -Tyr(3) octreotide (DOTATOC) positron emission tomography (PET)/CT in five cases of ectopic adrenocorticotropin-secreting tumours. Clin Endocrinol 81(1):152153

Guyton AC, Hall JE (2000) The adrenocortical hormones. In: Guyton AC, Hall JE (eds) The textbook of medical physiology. WB Saunders, Philadelphia, pp 869-883

Haug AR, Assmann G, Rist C, Tiling R, Schmidt GP, Bartenstein P, Hacker M (2010) Quantification of immunohistochemical expression of somatostatin receptors in neuroendocrine tumors using 68Ga-DOTATATE PET/CT. Radiologe. 50(4):349-354. https://doi.org/10.1007/s00117-009-1972-2

Haug AR, Cindea-Drimus R, Auernhammer CJ, Reincke M, Wängler B, Uebleis C et al (2012) The role of 68Ga-DOTATATE PET/ CT in suspected neuroendocrine tumors. J Nucl Med 53(11):1686-1692. https://doi.org/10.2967/jnumed.111.101675

Ilias I, Torpy DJ, Pacak K, Mullen N, Wesley RA, Nieman LK (2005) Cushing's syndrome due to ectopic corticotropin secretion: twenty years' experience at the National Institutes of Health. J Clin Endocrinol Metab 90(8):4955-4962. https://doi.org/1 $0.1210 /$ jc.2004-2527

Invitti C, Pecori Giraldi F, de Martin M, Cavagnini F (1999) Diagnosis and management of Cushing's syndrome: results of an Italian multicentre study. Study Group of the Italian Society of Endocrinology on the Pathophysiology of the Hypothalamic-Pituitary-Adrenal Axis. J Clin Endocrinol Metab 84(2):440-448. https://doi.org/10.1210/jcem.84.2.5465

Isidori AM, Kaltsas GA, Pozza C, Frajese V, Newell-Price J, Reznek RH, Jenkins PJ, Monson JP, Grossman AB, Besser GM (2006) The ectopic adrenocorticotropin syndrome: clinical features, diagnosis, management, and long-term follow-up. J Clin Endocrinol Metab 91(2):371-377. https://doi.org/10.1210/jc.2005-1542

Kakade HR, Kasaliwal R, Jagtap VS, Bukan A, Budyal SR, Khare S, Lila AR, Bandgar T, Menon PS, Shah NS (2013) Ectopic ACTHsecreting syndrome: a single-center experience. Endocr Pract 19(6):1007-1014. https://doi.org/10.4158/EP13171.OR

Kwekkeboom DJ, Krenning EP, Scheidhauer K, Lewington V, Lebtahi R, Grossman A, Vitek P, Sundin A, Plöckinger U, Mallorca Consensus Conference participants, European Neuroendocrine Tumor Society (2009) Mallorca Consensus Conference participants; European Neuroendocrine Tumor Society. ENETS Consensus Guidelines for the Standards of Care in Neuroendocrine Tumors: somatostatin receptor imaging with (111)In-pentetreotide. Neuroendocrinology. 90(2):184-189. https://doi.org/10.1159/000225946

Newell-Price J, Bertagna X, Grossman AB, Nieman LK (2006) Cushing's syndrome. Lancet. 367(9522):1605-1617. https://doi. org/10.1016/S0140-6736(06)68699-6

Özkan ZG, Kuyumcu S, Balköse D, Ozkan B, Aksakal N, Yılmaz E, Sanlı Y, Türkmen C, Aral F, Adalet I (2013) The value of somatostatin receptor imaging with In-111 Octreotide and/or Ga-68 DOTATATE in localizing Ectopic ACTH producing tumors. Mol Imaging Radionucl Ther 22(2):49-55. https://doi.org/10.4274/Mirt.69775

Pape UF, Perren A, Niederle B, Gross D, Gress T, Costa F, Arnold R, Denecke T, Plöckinger U, Salazar R, Grossman A, Barcelona Consensus Conference participants (2012) Barcelona Consensus Conference participants. ENETS Consensus Guidelines for 
the management of patients with neuroendocrine neoplasms from the jejuno-ileum and the appendix including goblet cell carcinomas. Neuroendocrinology. 95(2):135-156. https://doi.org/10.1159/000335629

Prasad V, Ambrosini V, Hommann M, Hoersch D, Fanti S, Baum RP (2010) Detection of unknown primary neuroendocrine tumours (CUP-NET) using (68)Ga-DOTA-NOC receptor PET/CT. Eur J Nucl Med Mol Imaging 37(1):67-77. https://doi.org/1 0.1007/s00259-009-1205-y

Schalin-Jäntti C, Ahonen A, Seppänen M (2012) 18F-DOPA PET/CT but not 68Ga-DOTA-TOC PET/CT revealed the underlying cause of ectopic Cushing syndrome. Clin Nucl Med 37(9):904-905. https://doi.org/10.1097/RLU.0b013e318262adc7

Shimon I, Taylor JE, Dong JZ, Bitonte RA, Kim S, Morgan B, Coy DH, Culler MD, Melmed S (1997) Somatostatin receptor subtype specificity in human fetal pituitary cultures. Differential role of SSTR2 and SSTR5 for growth hormone, thyroidstimulating hormone, and prolactin regulation. J Clin Invest 99(4):789-798. https://doi.org/10.1172/JCl119225

Singer J, Werner F, Koch CA, Bartels M, Aigner T, Lincke T, Fasshauer M, Paschke R (2010) Ectopic Cushing's syndrome caused by a well differentiated ACTH-secreting neuroendocrine carcinoma of the ileum. Exp Clin Endocrinol Diabetes 118(8): 524-529. https://doi.org/10.1055/s-0029-1243634

Swearingen B, Katznelson L, Miller K, Grinspoon S, Waltman A, Dorer DJ, Klibanski A, Biller BMK (2004) Diagnostic errors after inferior petrosal sinus sampling. J Clin Endocrinol Metab 89(8):3752-3763. https://doi.org/10.1210/jc.2003-032249

Tabarin A, Valli N, Chanson P, Bachelot Y, Rohmer V, Bex-Bachellerie V, Catargi B, Roger P, Laurent F (1999) Usefulness of somatostatin receptor scintigraphy in patients with occult ectopic adrenocorticotropin syndrome. J Clin Endocrinol Metab 84(4):1193-1202. https://doi.org/10.1210/jcem.84.4.5583

Thomas T, Zender S, Terkamp C, Jaeckel E, Manns MP (2013) Hypercortisolaemia due to ectopic adrenocorticotropic hormone secretion by a nasal paraganglioma: a case report and review of the literature. BMC Res Notes 6(1):331. https:// doi.org/10.1186/1756-0500-6-331

Torpy DJ, Chen CC, Mullen N, Doppman JL, Carrasquillo JA, Chrousos GP et al (1999) Lack of utility of (111)In-pentetreotide scintigraphy in localizing ectopic ACTH producing tumors: follow-up of 18 patients. J Clin Endocrinol Metab 84(4):11861192. https://doi.org/10.1210/jcem.84.4.5576

Treglia G, Salomone E, Petrone G, Giaccari A, Rindi G, Rufini V (2013) A rare case of ectopic adrenocorticotropic hormone syndrome caused by a metastatic neuroendocrine tumor of the pancreas detected by 68Ga-DOTANOC and 18F-FDG PET/CT. Clin Nucl Med 38(7):e306-e308. https://doi.org/10.1097/RLU.0b013e318279ec68

Tsagarakis S, Christoforaki M, Giannopoulou H, Rondogianni F, Housianakou I, Malagari C, Rontogianni D, Bellenis I, Thalassinos N (2003) A reappraisal of the utility of somatostatin receptor scintigraphy in patients with ectopic adrenocorticotropin Cushing's syndrome. J Clin Endocrinol Metab 88(10):4754-4758. https://doi.org/10.1210/jc.2003-03 0525

Veit JA, Boehm B, Luster M, Scheuerle A, Rotter N, Rettinger G, Scheithauer M (2013) Detection of paranasal ectopic adrenocorticotropic hormone-secreting pituitary adenoma by Ga-68-DOTANOC positron-emission tomographycomputed tomography. Laryngoscope. 123(5):1132-1135. https://doi.org/10.1002/lary.23867

Venkitaraman B, Karunanithi S, Kumar A, Bal C, Ammini AC, Kumar R (2014) ${ }^{68} \mathrm{Ga-DOTATOC} \mathrm{PET-CT} \mathrm{in} \mathrm{the} \mathrm{localization} \mathrm{of}$ source of ectopic ACTH in patients with ectopic ACTH-dependent Cushing's syndrome. Clin Imaging 38(2):208-211. https://doi.org/10.1016/j.clinimag.2013.10.007

Willhauck MJ, Pöpperl G, Rachinger W, Giese A, Auernhammer CJ, Spitzweg C (2012) An unusual case of ectopic ACTH syndrome. Exp Clin Endocrinol Diabetes 120(2):63-67. https://doi.org/10.1055/s-0031-1297967

Zemskova MS, Gundabolu B, Sinaii N, Chen CC, Carrasquillo JA, Whatley M, Chowdhury I, Gharib AM, Nieman LK (2010) Utility of various functional and anatomic imaging modalities for detection of ectopic adrenocorticotropin-secreting tumors. J Clin Endocrinol Metab 95(3):1207-1219. https://doi.org/10.1210/jc.2009-2282

Zhao X, Xiao J, Xing B, Wang R, Zhu Z, Li F (2014) Comparison of 68Ga DOTATATE to 18F-FDG uptake is useful in the differentiation of residual or recurrent pituitary adenoma from the remaining pituitary tissue After Transsphenoidal Adenomectomy. Clin Nucl Med 39(7):605-608. https://doi.org/10.1097/RLU.0000000000000457

\section{Publisher's Note}

Springer Nature remains neutral with regard to jurisdictional claims in published maps and institutional affiliations.

\section{Submit your manuscript to a SpringerOpen ${ }^{\circ}$ journal and benefit from:}

- Convenient online submission

Rigorous peer review

- Open access: articles freely available online

- High visibility within the field

- Retaining the copyright to your article

Submit your next manuscript at $\boldsymbol{s p r i n g e r o p e n . c o m ~}$ 